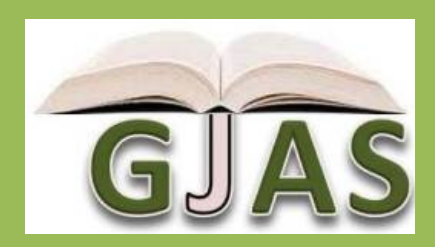

\title{
Simple Embryo Isolation Techniques from Ophrys (Orchidaceae) Seeds
}

\section{Mehmet Aybeke}

Trakya University, Faculty of Science, Dept. of Biology, Balkan Campus, 22030 Edirne, Turkiye.

\section{ARTICLE INFO}

Article No.: 030413509

DOI: 10.15580/GJAS.2013.6.030413509

Submitted: 03/04/2013

Accepted: 22/06/2013

Published: 29/06/2013

${ }^{*}$ Corresponding Author

Mehmet Aybeke

E-mail: mehmetaybeke

@yahoo.com

Phone: +90 5062931789, Office:

+902842352824 (1183)

\section{Keywords:}

Barlia, Embryo, Orchid, Seed

isolation
Investigations on embryos and seeds are very difficult, owing to the fact that orchid seeds are very small, dusty, and transparent. Therefore, this study looked at how to prepare the isolation technique for orchid seeds and how to isolate orchid embryos from seeds. The seeds of Barlia robertiana (Orchidaceae) were used. Consequently, for orchid seeds, the most suitable isolation method was established and its practical importance is discussed. 


\section{INTRODUCTION}

Orchid seeds are very small and transparent. Embryos in seeds may barely be seen by means of a microscope. Embryos take up little space in the seeds. Thus, orchid seeds may travel great distances in the air due to their fusiform aerodynamic features and lightweight properties (Fitzgerald, 1888; Hatch, 1952; Dockrill, 1969).Furthermore, the color, shape of the testa, and the embryo are systematically significant. Systematic studies have been performed on epiphytic and terrestrial orchids to date. Regarding European and Turkish orchids, several morphological, palynological, embryological, karyological, and anatomical studies have been carried out (Sezik 1984, 1988; Aybeke, 1997, 2000, 2002, 2004, 2007a-b, 2010). However, working with orchid seeds is very difficult because of their small morphology; for example, Ophrys mammosa seeds are $0.557 \mu \mathrm{m}$ in length and $0.138 \mu \mathrm{m}$ in width. Its embryos are smaller than the seeds: $0.107 \mu \mathrm{m}$ in length and $0.062 \mu \mathrm{m}$ in width (Aybeke, 2007a). Therefore, investigation of the seeds in liquid isolation media will be easier. This way, both the inner and outer morphological properties of the testa will be investigated by part or full isolation, and all anatomical and embryological characteristics of the extracted embryos will be uncovered. At this point, it was necessary to investigate the orchid seeds with a suitable isolation technique. Therefore, the aim was to establish a suitable isolation method for orchid seeds and embryos.

\section{Experiment}

The seeds of Barlia robertiana (Loisel.) Greuter (Orchidaceae) were used. Firstly, the seeds were fixed in FAA $(0.5 \mathrm{ml}$ glacial acetic acid $+0.5 \mathrm{ml}$ formalin $36 \%+9 \mathrm{ml}$ alcohol $70 \%$ ) at room conditions for $1.5 \mathrm{~h}$. The material was washed twice by $70 \%$ alcohol for 1 $\min$, and then passed through a series of $50 \%$ and $30 \%$ alcohol and tap water for a total of $3 \mathrm{~min}$. The water in the test tube was carefully removed. Tap water and pure $\mathrm{H}_{2} \mathrm{SO}_{4}$ (volume 1:1) were respectively added to the tube and were heated intermittently in a light flame for $4 \mathrm{~min}$. Then, one volume of chromic acid $(20 \%)$ was added into the same test tube. With this addition, the test tube was intermittently on a light flame for $18.5 \mathrm{~min}$. Afterward, tap water with the same amount of total isolation fluid was added into the test tube, and the isolation process was terminated.

Except for the heating procedure, all parts of the isolation process were carried out by rinsing carefully on a shaker until the liquid was transparent; the liquid was then replaced with new tap water several times. Therefore, this final transparent fluid is the isolated stock solution. Except for the isolation process (with $\mathrm{H}_{2} \mathrm{SO}_{4}$ and chromic acid application), in all the other fixations, including the washing and the end phase with the addition of tap water, the homogenate was centrifuged at $3000 \mathrm{rpm}$ for nearly 1 -
1.30 min. Afterward, every centrifugation supernatant was carefully removed. For partial isolation, the heating process was shorter. In this isolation process, after the addition of chromic acid, the homogenate was subjected to intermittent heating for only 8-10 min, instead of $18.5 \mathrm{~min}$, as described above, and for the end process, tap water was added. Another partial isolation method is as follows. The seeds were fixed and washed, as described previously. The material was subjected to $2 \mathrm{~N} \mathrm{HCl}$ at $60 \stackrel{\circ}{\circ} \mathrm{C}$ for $30 \mathrm{~min}$ in an incubator. The homogenate was centrifuged at 3000 rpm for 1.5 min and then tap water was added into the tube. The washing was repeated a few times and each time, the homogenate was centrifuged.

After the last wash and centrifugation, the supernatant was removed and placed into the tube, after which $20 \%$ chromic acid was added. Thus, the material was placed in an incubator at $60^{\circ} \mathrm{C}$ for $2.5 \mathrm{~h}$ for partial testa isolation.

\section{RESULTS and DISCUSSION}

In order for the seed testa, the embryo, and the suspensor to be seen all together, the procedure should be terminated in 10 min (Figure 2-3). To investigate only the testa structure, the $\mathrm{HCl}$-chromic acid method is more useful. It was determined that the embryos and suspensors, altogether, separated from the testa during isolation, especially with the 18-19 min of $\mathrm{H}_{2} \mathrm{SO}_{4}$-chromic acid method (Figure 4-6).

The $\mathrm{H}_{2} \mathrm{SO}_{4}$-chromic acid method appeared to show more effective and faster results. In particular, the initial fixation procedure minimized the protoplasmic degenerations that could arise from the future isolation process. Therefore, depending on the intended object (testa, embryo, suspensor, or all together), the two different methods, as described above, can be easily applied. From our literature review, there was only one "squashing technique" study on orchid embryos, but this technique is not applicable for mature seeds and embryos. Therefore, our method is more convenient and practices. In addition, one of the distinctive features of orchid embryos is the diverse morphology of their suspensors. In 1949, Swamy devised a classification scheme for orchid embryo development based on suspensor morphology alone. Depending on the species, the suspensor of orchids may be unicellular or may consist of a few filamentous cells (Swamy, 1949; Clements, 1999). Furthermore, investigating such small seeds and embryos by using a common paraffin section method will be very difficult, and the results will mainly be coincidental. Consequently, this technique will, undoubtedly, contribute to orchid seed anatomy as well as several cytoembryological and molecular studies on orchid embryos. 

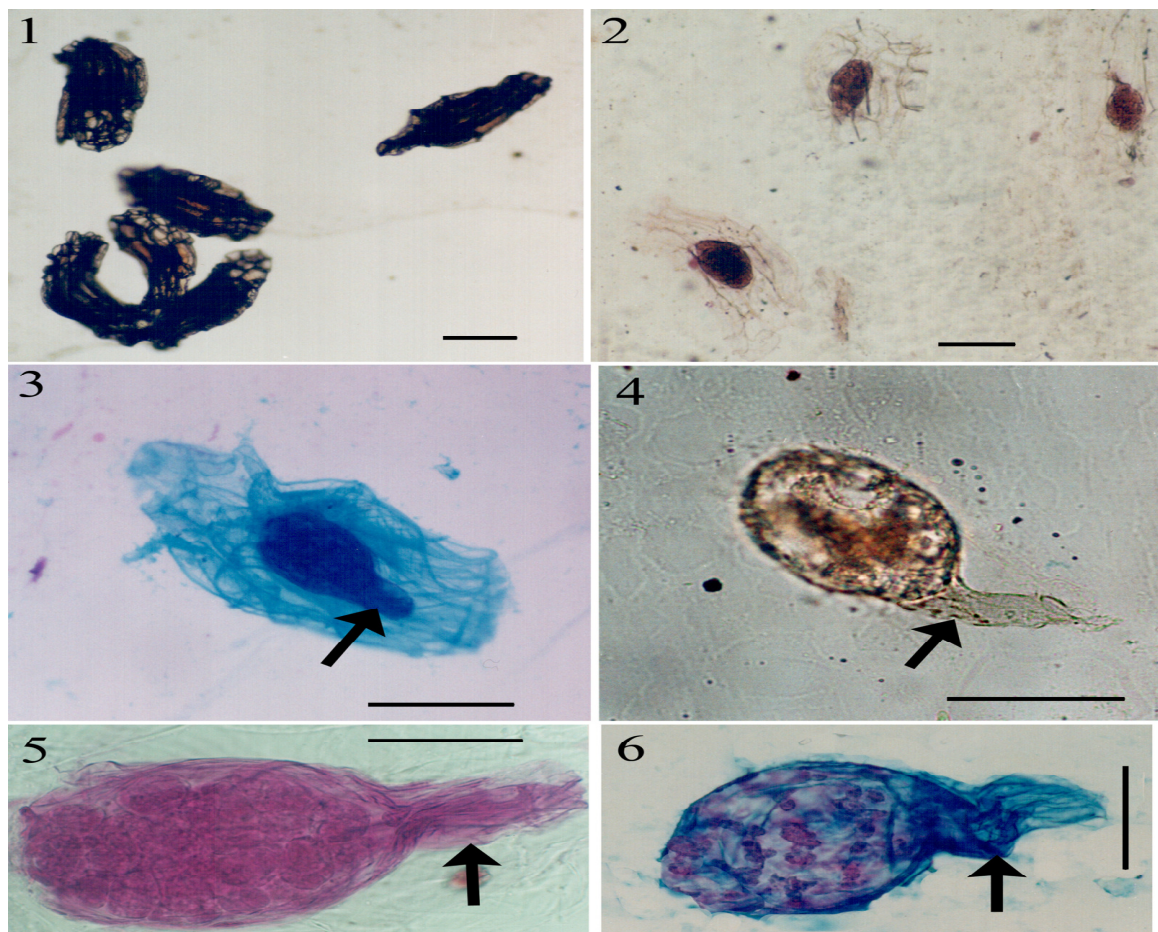

Figure. 1-6: 1. Intact Ophrys seeds. 2. Partially processed Ophrys seeds with 10 min of the $\mathrm{H}_{2} \mathrm{SO}_{4}$ chromic acid method, and one of these seeds is magnified in Fig. 3; 4-5-6. Embryos extracted from seeds with 18 min of the $\mathrm{H}_{2} \mathrm{SO}_{4}$-chromic acid method (note: in all figures the arrows indicate the suspensors of embryos). Bars: 1, 2: $100 \mu, 3: 160 \mu, 4,5,6: 50 \mu$.

\section{REFERENCES}

Aybeke, M, "Morphological, caryological and palynological studies Ophrys L (Orchidaceae) Edirne Environ" Trakya Üniversity, Graduate school of Natural and Applied Sciences, Master thezis, Edirne, , (1997).

Aybeke, M, "Caryological studies on Ophrys L. (Orchidaceae) species in Edirne environ", Systematic Botanik Herb 7(1): 187-196, (2000).

Aybeke, M., "In vitro germination experiments on granular pollens and polliniums in orchids", Gazi University, Journal of Science, 15(1): 71-80, (2002).

Aybeke, M., "Anatomical studies on some orchids growing in Trakya region", Trakya Üniversity, Graduate school of Natural and Applied Sciences, PH thezis, Edirne, (2004).

Aybeke, M.,. "The Pollen and Seed Morphology of some Ophrys L. (Orchidaceae), Taxa”, Journal of Plant Biology 50 (4): 387-395. (2007a)

Aybeke, M., "Ophrys heldreichii, Orchis punctulata (Orchidaceae)" in: New Floristic Records in the Balkans 5 (V. Vladimirov, F.Dane, V.Matevski, K. Tan, eds.). Phytologica Balcanicae 13 (2): 291-306, (2007b).
Aybeke, M., Sezik, E. \& Olgun, G., "Vegetative anatomy of some Ophrys, Orchis and Dactylorhiza (Orchidaceae) taxa in Trakya region of Turkey", Flora 205 (2): 73-89, (2010)

Clements, M.A.,. "Embryology" in: Pridgeon AM, Cribb PJ, Chase MW, Rasmussen FN (eds.) Genera Orchidacearum, vol. 1, pp: 38-66. Oxford: Oxford University Press, (1999).

Dockrill, A.W., "Australian Indigenous Orchids", Vol 1. The Society for Growing Australian Plants. Sydney: Halstead Press, (1969)

Fitzgerald, R.D., "Australian Orchids", Vol 1. Charles Porter, Government Printer, (1888).

Hatch, E.D., "The New Zealand forms of Thelymitra JR and G Forster and appendices", Trans Roy Soc NZ 79: 386402, (1952).

Sezik, E., "Orkidelerimiz, Türkiyenin Orkideleri", Sandoz Kültür Yayınları No: 6, İstanbul, (1984).

Sezik, E., "Trakya'da yetişen Orchidaceae Türleri”, Trakya florası sempozyumu bildiri özetleri (Trakya Üniv., Fen Ed.fak. 28-29 nisan, Edirne), (1988).

Swamy, B.G.L., "Embryological studies in the Orchidaceae II, Embryology", The American Midland Naturalist 41: 202-232, (1949).

Cite this Article: Aybeke M (2013). Simple Embryo Isolation Techniques from Ophrys (Orchidaceae) Seeds. Greener Journal of Agricultural Sciences, 3(6): 448-450, http://doi.org/10.15580/GJAS.2013.6.030413509. 